\title{
Pregnancy Incidence in Norwegian Red Cows Using Nonreturn to Estrus, Rectal Palpation, Pregnancy-Associated Glycoproteins, and Progesterone
}

\author{
R. T. Garmo, ${ }^{\star 1}$ A. O. Refsdal,† K. Karlberg, ${ }^{*}$ E. Ropstad, ${ }^{*}$ A. Waldmann,‡ J. F. Beckers,§ and O. Reksen \\ *Department of Production Animal Clinical Sciences, Norwegian School of Veterinary Science, PO Box 8146, NO-0033 Oslo, Norway \\ †Geno Breeding and Al Association, Holsetgata 22, 2326 Hamar, Norway \\ ‡Estonian University of Life Sciences, 62 Kreutzwaldi Street, 51014 Tartu, Estonia \\ §University of Liege, Faculty of Veterinary Medicine, B 4000 Sart-Tilman, Belgium
}

\begin{abstract}
The objectives of the study were to estimate pregnancy incidence and calving rate after first artificial insemination (AI) in Norwegian Red cows undergoing spontaneous estrus, to assess the relationship between pregnancy and management factors at herd or cow level, to evaluate differences between 60-d nonreturn rate (NRR60d) and pregnancy incidence, and to compare the accuracy of pregnancy diagnosis by rectal palpation and plasma pregnancy-associated glycoproteins (PAG) analysis supported by progesterone measurements. In total, 829 animals ( $\mathrm{n}=229$ heifers, 234 firstlactation, 173 second-lactation, and $193>$ second-lactation cows) were included. Milk samples for progesterone analysis were collected both at AI and 3 wk later. Cows with progesterone concentrations $<3 \mathrm{ng} / \mathrm{mL}$ at AI were considered in estrus or having nonactive ovaries, whereas cows with progesterone concentrations $>7 \mathrm{ng} /$ $\mathrm{mL} 3$ wk later were considered pregnant. Blood sampling for PAG analysis and pregnancy diagnosis by rectal palpation were conducted $57.6 \pm 0.92 \mathrm{~d}$ after AI. Pregnancy-associated glycoprotein concentrations equal to $2.5 \mathrm{ng} / \mathrm{mL}$ gave the greatest sensitivity $(94.3 \%)$ and specificity (94.6\%) in the assessment of pregnancy. The number of days from calving to first AI was 85.3 \pm 1.71 . Overall NRR60d after first AI was $72.5 \%$. The corresponding values for heifers, first-lactation, secondlactation, and >second-lactation cows were 76.9, 67.1, 69.9 , and $76.2 \%$. Overall pregnancy incidence after first AI was $63.7 \%$. The corresponding values for heifers, first-lactation, second-lactation, and >second-lactation cows were $70.0,58.2,61.6$, and $64.9 \%$. Overall calving rate to first $\mathrm{AI}$ was $57.2 \%$. The corresponding values for heifers, first-lactation, second-lactation, and >secondlactation cows were $64.9,54.3,54.7$, and $53.9 \%$. The overall difference between NRR60d and pregnancy inci-
\end{abstract}

Received October 15, 2007.

Accepted April 23, 2008.

${ }^{1}$ Corresponding author: randi.garmo@veths.no dence was $8.8 \%$, whereas the parity-specific differences were $6.9,8.9,8.3$, and $11.3 \%$ for heifers, first-lactation, second-lactation, and >second-lactation cows, respectively. Eight animals with PAG $<2.5 \mathrm{ng} / \mathrm{mL}$ and classified as pregnant by rectal palpation calved, whereas 5 animals with PAG $\geq 2.5 \mathrm{ng} / \mathrm{mL}$ and classified as nonpregnant by rectal palpation also calved. The study showed that Norwegian Red cows have relatively high reproductive performance. Breeding for fertility traits over $35 \mathrm{yr}$ is probably an important reason for such high fertility.

Key words: pregnancy incidence, dairy cow, reproductive performance

\section{INTRODUCTION}

Since the 1970s, milk yield per cow has increased because of intense genetic selection, improved management, and better nutrition (Lucy, 2001). Yet fertility in dairy cows has declined in recent decades, resulting in economic losses in the dairy industry. There is ongoing discussion about reasons for infertility in dairy cows, including factors such as increased milk production associated with negative energy balance, larger herd size, and greater inbreeding percentages. To improve fertility in dairy cows, several estrous cycle management systems, involving use of reproductive hormones and timed AI, were developed (Thatcher et al., 2006). There are a few published studies from recent years in which cows were inseminated at spontaneously occurring estrus (Andersson et al., 2006; Cairoli et al., 2006) compared with induced estrus and timed AI (Lopez-Gatius et al., 2004; Howard et al., 2006). In the Norwegian dairy industry, pharmacological methods to control estrous cycles are not routinely used, and pharmaceutical treatment of reproductive disorders is only applied after clinical examination and diagnosis (Østerås et al., 2007).

Despite modern estrous cycle management systems, fertility is still declining and the importance of the inclusion of fertility-related traits in the genetic selection 
indices used for the dairy industry has been stressed (Philipsson and Lindhé, 2003; Chagas et al., 2007). Contrary to breeding management in most countries, female fertility has been included in the total merit index for the Norwegian Red breed since 1972. The relative weight on fertility has been 8 to $15 \%$ over the entire period (Andersen-Ranberg et al., 2005). Reproductive performance in the breed increased throughout the last decade despite a moderate increase in milk yield (Østerås et al., 2007; Refsdal, 2007). Therefore, an assessment of the pregnancy incidence in the Norwegian Red may be used to indicate the potential of improvement in breeds that have experienced impaired reproductive performance during the same period.

Nonreturn rate has been regarded as a reasonably accurate indicator of reproductive performance. Moreover, the nonreturn rate to first AI will be biased because of variation in breeding management, culling practices, season, parity, season of semen collection, and type of bull used (Haugan et al., 2005; Refsdal, 2007). A good estimate of the pregnancy incidence in Norwegian Red is not available because only $50 \%$ of the cows in Norway are pregnancy diagnosed by rectal palpation (Reksen et al., 1999). From an international perspective, there is increasing interest in importing Norwegian Red semen for improvement of reproductive efficiency. Thus, more accurate information about the pregnancy incidence and calving rate of the breed is required.

Pregnancy diagnosis by rectal palpation is the most common way to assess pregnancy. However, pregnancyassociated glycoproteins (PAG) can be used for pregnancy diagnosis. Pregnancy-associated glycoproteins constitute a large family of glycoproteins specifically expressed in the outer epithelial cell layer (trophectoderm or chorion) of the placenta in ungulate species (Xie et al., 1997). Although their function remains unknown, PAG can be detected in the maternal blood from around wk 3 of pregnancy (Zoli et al., 1992). Plasma PAG concentrations were useful for pregnancy diagnosis $28 \mathrm{~d}$ after AI, provided that the time interval between calving and $\mathrm{AI}$ is at least $60 \mathrm{~d}$ (Haugejorden et al., 2006).

The objectives were 1) to estimate the pregnancy incidence and calving rate to first AI after spontaneous estrus in Norwegian Red cows; 2) to assess the relationship between pregnancy and management factors at herd or cow level; 3) to evaluate differences between nonreturn rate at $60 \mathrm{~d}$ (NRR60d) and pregnancy incidence; and 4) to compare the accuracy of pregnancy detection by rectal palpation with PAG analysis supported by progesterone measurements.

\section{MATERIALS AND METHODS}

The study began in October 2004, and ended in October 2005 . Veterinary practices were selected for inclu- sion on the basis of being located within a short geographical distance from the Norwegian School of Veterinary Science, and the Norwegian AI and breeding association, Geno (Hamar, Norway). The ambulatory clinic at the Norwegian School of Veterinary Science (Akershus County) performed 104 AI. There were 19 AI technicians and veterinarians (AI personnel) in Oppland and Hedmark counties who participated in the study with a range from 1 to $187 \mathrm{AI}$ (median $=20$ ). The AI were performed in 308 herds with AI ranging from 1 to 20 (median =2). Among 596 cows with designated housing systems, 116 cows were managed in 41 freestall herds, whereas 480 cows were managed in 219 tiestall herds. The unit of the study was cows or heifers presented for first AI. Treatment with reproductive hormones for reproductive disorders during the current lactation or at all for heifers was an exclusion criterion. In total, 851 animals were enrolled but 22 animals were excluded because of previous AI ( $n=17)$, treatment for reproductive disorders $(\mathrm{n}=4)$, or belonging to a breed other than Norwegian Red ( $\mathrm{n}=1$ ); thus, the total number of animals included in the analyses was 829 . For 7 animals ( 2 heifers and 5 cows) data for nonreturn rate and calving were available, but data for pregnancy diagnosis were missing. For 2 cows data for calving or culling were missing.

Milk samples for progesterone analyses were obtained by the farmer or $\mathrm{AI}$ personnel at $\mathrm{AI}$ and $3 \mathrm{wk}$ later. A tablet of Broad Spectrum Microtab (D\&F Control Systems Inc., Dublin, CA) was added as a preservative, and the milk samples were stored frozen until assayed for progesterone content. Progesterone concentrations in milk were measured by an enzyme immunoassay (Waldmann, 1993), modified by using the secondantibody coating technique. The specificity of the antibody was described (Waldmann, 1999). The interassay coefficients of variation for milk progesterone concentrations of 1.48 and $19.66 \mathrm{ng} / \mathrm{mL}$ were 9.2 and $5.3 \%$, respectively. The intraassay coefficient of variation was $<10 \%$.

Blood samples for PAG were collected at the time of rectal examination for pregnancy performed by veterinarians preferably 6 wk after AI, if the animal did not return to estrus. A heterologous double-antibody RIA, modified from the method described previously by Zoli et al. (1992), was used to determine PAG concentrations in the plasma. Bovine PAG (bPAG) was used as standard and tracer, anti-caprine $\mathrm{PAG}_{708,709}$ as first antibody (Garbayo et al., 1998), and sheep anti-rabbit IgG as the second antibody for precipitation. The anti-caprine $\mathrm{PAG}_{708,709}$ cross-reacts with the bovine plasma. Because plasma dilutions did not completely parallel the standard curve, the assay must be regarded as semiquantitative. The standard curve ranged from 0.2 to 25 
ng of bPAG equivalents/mL. To minimize nonspecific interferences, zero plasma was added to all standard tubes. Samples and standards were incubated with antibody overnight at room temperature, and labeled bPAG $(33,333 \mathrm{dpm})$ was added the following day and incubated for a further $4 \mathrm{~h}$ at room temperature. Sheep anti-rabbit IgG was added, and free and bound fractions were separated by centrifugation $(3,400 \times g$ for $15 \mathrm{~min})$. The precipitates were counted in a Wizard Gamma Counter (Wallac, Turku, Finland). Interassay coefficients of variation were $11.6 \%$ (2.59 ng of bPAG equivalents $/ \mathrm{mL}$ ) and $5.0 \%$ (10.27 $\mathrm{ng}$ of bPAG equivalents $/ \mathrm{mL}$ ), respectively. Assay sensitivity was $0.80 \mathrm{ng}$ of bPAG equivalents/mL.

Data on previous calving date, date of AI, date of new AI, date for next calving, use of double AI (new AI within 0 to $3 \mathrm{~d}$ ), parity, the milk yield measure within $43 \mathrm{~d}$ after AI, heifers' age at AI, AI personnel, herd size, culling date, and reasons for culling were obtained from the National Dairy Herd Recording System (NDHRS) files (Tine BA, Ås, Norway).

\section{Determination of Pregnancy Incidence}

The most reliable standard for pregnant animals was considered to be animals calving after first AI ( $n=473$ of 827 animals). Among animals that calved, the criteria used to determine whether the pregnancy was because of the reported AI were either a gestation period of $<295$ $\mathrm{d}$ without a recording on new AI, or return to estrus 18 to $24 \mathrm{~d}$ after first AI. For animals with a gestation period $>290 \mathrm{~d}$, the identity of the sire and the bull used at AI was controlled using the NDHRS files.

For cows with uncertain pregnancy status that did not calve within the defined gestation period, rectal palpation and progesterone measurements were considered in addition to PAG analysis. By including these criteria to determine pregnancy, the numbers of pregnant animals increased by 51; thus, the total number of pregnant animals was 524 .

Analysis of Milk Progesterone. A progesterone concentration of $7 \mathrm{ng} / \mathrm{mL}$ was chosen as the threshold value for the indication of pregnancy 3 wk after first AI. This threshold value was based on the lowest milk progesterone values observed in pregnant animals of the current study. Milk progesterone concentrations 3 wk after AI in 4 pregnant cows that calved 280, 282, 278, and $280 \mathrm{~d}$ after first AI were 7.1, 8.0, 9.4, and 9.8 $\mathrm{ng} / \mathrm{mL}$, respectively. A threshold value of milk progesterone $\geq 3 \mathrm{ng} / \mathrm{mL}$ (Royal et al., 2000; Petersson et al., 2007) indicated luteal activity. Thus, to be compatible with pregnancy, milk progesterone concentrations at AI needed to be $<3 \mathrm{ng} / \mathrm{mL}$, and $>7 \mathrm{ng} / \mathrm{mL}$ at the second milk sample obtained 3 wk later. Progesterone concen- tration $\geq 3 \mathrm{ng} / \mathrm{mL}$ in the first milk sample was indicative of $\mathrm{AI}$ in diestrus.

Analysis of PAG. The PAG value for determination of pregnancy was interpolated to an estimated PAG value at d 42 for all cows. The natural logarithm of PAG was used for the estimation, and regressed against days from AI to blood sampling. The coefficient $\beta=$ 0.01978 was used to obtain the changes in PAG per day. The adjusted 42-d PAG value for the pregnant animals that delivered a calf $(n=473)$ was used to create a sensitivity curve for PAG. Animals whose blood was analyzed for PAG concentrations but were determined nonpregnant $(\mathrm{n}=37)$ were used to create a specificity curve for PAG. Animals used to create a specificity curve had progesterone concentrations $<3 \mathrm{ng} / \mathrm{ml}$ at AI and $\leq 7 \mathrm{ng} / \mathrm{mL} 3$ wk after AI or PAG value $<0.5 \mathrm{ng} / \mathrm{mL}$ or both in addition to being evaluated nonpregnant by rectal palpation.

Rectal Palpation. Local veterinarians were instructed to perform pregnancy examinations approximately 6 wk after AI by rectal palpation simultaneously with blood sampling for animals believed pregnant because of nonreturn to estrus or rebreeding.

\section{Pregnancy Diagnosis by PAG and Rectal Palpation}

Only cows that calved after first AI $(n=473)$ were used to determine the accuracy of pregnancy diagnosis by rectal palpation and by PAG analysis. Fourteen of these animals had no measurements for PAG, and 2 had no records of pregnancy examination; all 16 animals were excluded from the evaluation of the accuracy of pregnancy diagnosis by rectal palpation and PAG analysis.

\section{Statistical Analyses}

The calculation of NRR60d, pregnancy incidence, and calving rate was performed separately for all AI and for single AI only. The relationships between the outcome pregnant or nonpregnant and the predictor variables were tested both univariately using ordinary logistic regression in SPSS (SPSS Inc., 2004), and in multivariable analysis using a general estimating equation (GEE) approach with the GENMOD procedure in SAS (Stokes et al., 1995).

The following variables were included when the likelihood of pregnancy ( 1 or 0 ) was evaluated in the univariate logistic regression model: milk yield at the DIM closest to AI (milk yield), heifers' age at AI, days from calving to first AI (CFI), lactation number (heifer, 1, 2, $>2$ ), season (Jan to March, April to June, July to Sep, and Oct to Dec), double AI, housing (tie stall, free stall), personnel performing AI, and herd size. Personnel per- 
forming $<30 \mathrm{AI}$ were categorized into one group, whereas personnel performing $\geq 30 \mathrm{AI}$ were included as single levels in the model. Herd size was categorized into 3 equally sized groups: 5.7 to $15.3,15.4$ to 21.3 , and 21.4 to 134.5 cow-years.

The univariate analyses were performed both simultaneously for all parities and separately for cows and heifers. Animals calving during January, February, and March; animals with a single AI during estrus; herd size from 5.7 to 15.3 cow-years; personnel performing <30 AI; and heifers were the designated comparison groups and were assigned the zero value of an odds ratio $=1$.

When the association between likelihood of pregnancy and milk yield was assessed, CFI was included in the model to adjust for changes in milk yield by DIM. Variables in the univariate analyses with a $P \leq 0.20$ (overall Wald statistics) were included in the multivariable model and the backward selection procedure was applied. The variable with the greatest $P$-value was omitted and only predictor variables with a $P \leq 0.20$ from the type 3 score statistics in the GEE analysis remained in the model. The following predictor variables remained in the model when the likelihood of pregnancy in all animals was assessed: lactation number, double AI ( 1 or 0 ), and AI personnel. None of the predictor variables remained in the heifer model. The following predictor variables remained in the model when the likelihood of pregnancy in cows was assessed: season, double AI (1 or 0 ), and CFI. Cows were nested within herd, which was accounted for by using a compound symmetry (exchangeable) correlation structure (Stokes et al., 1995). Confounding was assessed by com- paring crude and adjusted parameter estimates. If the estimates varied $>10 \%$, confounding was regarded as present (Dohoo et al., 2003).

\section{RESULTS}

The distribution of $\mathrm{AI}(\mathrm{n}=829)$ by parity for heifers, first-lactation, second-lactation, and >second-lactation cows is in Table 1. The overall average CFI interval was $85.3 \mathrm{~d}(\mathrm{SD} \pm 41.9)$. The corresponding values were $84.4 \pm 38.1,86.8 \pm 52.0$, and $84.9 \pm 35.8 \mathrm{~d}$ for firstlactation, second-lactation, and $>$ second-lactation cows, respectively. The proportion of double AI was evenly distributed by parity: heifers $10.5 \%$, first lactation $11.1 \%$, second lactation $9.8 \%$, and >second lactation $10.9 \%$. The number of days from first AI to blood sampling for PAG analysis and rectal palpation was $57.6 \pm$ $22.2 \mathrm{~d}(\mathrm{n}=584)$. Low progesterone concentration $(<3$ $\mathrm{ng} / \mathrm{mL}$ ) was present in $95.1 \%$ (520/547) of the cows at first AI, whereas progesterone concentration $\geq 3 \mathrm{ng} / \mathrm{mL}$ was detected in $4.9 \%(27 / 547)$ of the cows.

\section{Nonreturn Rate, Pregnancy Incidence, and Calving Rate}

Parity-specific NRR60d, pregnancy incidence, and calving rate, including double AI, are in Table 1.The difference between NRR60d and pregnancy incidence was $8.8 \%$. The parity-specific differences between NRR60d and pregnancy incidence were $6.9,8.9,8.3$, and $11.3 \%$ for heifers, first-lactation, second-lactation, and >second-lactation cows, respectively. The pregnancy incidence was $10.3 \%$ greater in heifers compared

Table 1. Overall and parity-specific 60-d nonreturn rate, pregnancy incidence at $6 \mathrm{wk}$, and calving rate in Norwegian Red cows after first $\mathrm{AI}^{1}$

\begin{tabular}{|c|c|c|c|c|c|c|}
\hline \multirow[b]{2}{*}{ Group } & \multicolumn{2}{|c|}{ Nonreturn rate } & \multicolumn{2}{|c|}{ Pregnancy incidence } & \multicolumn{2}{|c|}{ Calving rate } \\
\hline & $\mathrm{n} / \mathrm{n}$ & $\%$ & $\mathrm{n} / \mathrm{n}$ & $\%$ & $\mathrm{n} / \mathrm{n}$ & $\%$ \\
\hline All & $601 / 829$ & 72.5 & $524 / 822^{2}$ & 63.7 & $473 / 827^{2}$ & 57.2 \\
\hline Heifers & $176 / 229$ & 76.9 & $159 / 227$ & 70.0 & $148 / 228$ & 64.9 \\
\hline Cows & $425 / 600$ & 70.8 & $365 / 595$ & 61.3 & $325 / 599$ & 54.3 \\
\hline 1st lactation & $157 / 234$ & 67.1 & $135 / 232$ & 58.2 & $127 / 234$ & 54.3 \\
\hline 2nd lactation & $121 / 173$ & 69.9 & $106 / 172$ & 61.6 & $94 / 172$ & 54.7 \\
\hline$>2$ nd lactation & $147 / 193$ & 76.2 & $124 / 191$ & 64.9 & $104 / 193$ & 53.9 \\
\hline \multicolumn{7}{|l|}{ Single AI only } \\
\hline All & $532 / 741$ & 71.8 & $462 / 734^{2}$ & 62.9 & $416 / 739^{2}$ & 56.3 \\
\hline Heifers & $155 / 205$ & 75.6 & $143 / 203$ & 70.4 & $133 / 204$ & 65.2 \\
\hline Cows & $377 / 536$ & 70.3 & $319 / 531$ & 60.1 & $283 / 535$ & 52.9 \\
\hline 1st lactation & $139 / 208$ & 66.8 & $118 / 206$ & 57.3 & $111 / 208$ & 53.4 \\
\hline 2nd lactation & $106 / 156$ & 67.9 & $92 / 155$ & 59.4 & $81 / 155$ & 52.3 \\
\hline$>2$ nd lactation & $132 / 172$ & 76.7 & $109 / 170$ & 64.1 & $91 / 172$ & 52.9 \\
\hline
\end{tabular}

\footnotetext{
${ }^{1}$ Results are reported separately for all animals, including those that received double AI (new AI within 0 to $3 \mathrm{~d}, \mathrm{n}=829)$, and for animals that received only $1 \mathrm{AI}(\mathrm{n}=741)$.

${ }^{2}$ The different numbers of observations for nonreturn rate, pregnancy incidence, and calving rate are because of missing data for pregnancy diagnosis at $6 \mathrm{wk}$ for 7 animals, and missing data on calving date or culling date for 2 animals.
} 
Table 2. Univariate analysis for all parity groups, cow only, and heifers only, and $P$-value for the predictor variables: lactation number, days from calving to first AI (CFI), double AI (dAI), season, person performing AI (pAI), herd size, housing, heifers' age at AI, and milk yield in Norwegian Red cows

\begin{tabular}{lccc}
\hline Item & All & Cows & Heifers \\
\hline Parity & 0.04 & 0.37 & - \\
CFI & - & 0.17 & - \\
Season & 0.15 & 0.07 & 0.88 \\
dAI & 0.18 & 0.07 & 0.64 \\
pAI & 0.12 & 0.14 & 0.85 \\
Herd size & 0.81 & 0.43 & - \\
Housing & - & 0.44 & - \\
Heifers'age at AI & - & - & 0.73 \\
Milk yield & - & 0.95 & - \\
\hline
\end{tabular}

with cows. The corresponding fertility measures after a single AI are in Table 1.

\section{Univariate Analysis in Cows and Heifers}

Univariate models for the all parity groups, only cows, and only heifers and the predictor variables are presented in Table 2. Parity was the only significant predictor when both cows and heifers were included in the analysis.

\section{Milk Yield}

The milk recordings were obtained on $15 \pm 9.9 \mathrm{~d}$ after AI. Milk yield at the milk recording day, distributed by parity, was $22.6 \pm 4.5,26.4 \pm 5.4$, and $28.6 \pm 5.7 \mathrm{~kg}$ for first-lactation, second-lactation, and >second-lactation cows, respectively. There was no relationship between likelihood of pregnancy to first AI and the predictor variables milk yield and CFI.

\section{Multivariable Model}

For all animals, the overall type III statistics were not significant for lactation number $(P=0.13)$, double AI $(P=0.13)$, and person performing AI $(P=0.20)$. Estimates for each level of the predictors are presented in Table 3.

For cows, the overall type III statistic was not significant for CFI $(P=0.13)$, double AI $(P=0.08)$, or season $(P=0.19)$. Estimates for each concentration of the predictors are in Table 4. Confounding between the covariates was not apparent in the multivariable analyses.

\section{Sensitivity and Specificity for PAG}

The curves for sensitivity and specificity for PAG are in Figure 1. A PAG value of $2.5 \mathrm{ng} / \mathrm{mL}$ optimized the sensitivity (94.3\%) and specificity (94.6\%) in the assessment of pregnancy.

\section{Abortion and Early Partus}

The proportion of pregnant animals that aborted was $1.0 \%$ (5/524). The 5 animals aborted 62, 149, 243, 252, and $259 \mathrm{~d}$ after first AI. The proportion of animals that calved 260 to $269 \mathrm{~d}$ of gestation was $3.2 \%$ (17/524).

\section{Pregnant Animals Not Calving Within the Defined Gestation Period (<295 d)}

Fifty-one animals $(9.7 \%, 51 / 524)$ diagnosed pregnant 6 wk after first AI by progesterone, PAG, and rectal

Table 3. General estimating equation model for assessing the pregnancy incidence in heifers and cows of Norwegian Red from the following predictors: lactation number, double AI (dAI), and person performing AI

\begin{tabular}{|c|c|c|c|c|c|}
\hline Item & $\beta$ & SE & $\mathrm{df}$ & Odds ratio & $P$-value \\
\hline Intercept & 1.065 & 0.233 & - & 2.90 & $<0.01$ \\
\hline Heifers ${ }^{1}$ & - & - & - & - & - \\
\hline 1st lactation & -0.530 & 0.223 & 1 & 0.59 & 0.02 \\
\hline 2nd lactation & -0.404 & 0.224 & 1 & 0.67 & 0.07 \\
\hline$>2$ nd lactation & -0.238 & 0.225 & 1 & 1.25 & 0.29 \\
\hline $\mathrm{dAI}, \mathrm{no}^{1}$ & - & - & - & - & - \\
\hline dAI, yes & 0.445 & 0.288 & 1 & 1.56 & 0.12 \\
\hline$<30 \mathrm{AI}^{1,2}$ & - & - & - & - & - \\
\hline $\mathrm{A}^{3}$ & -0.614 & 0.261 & 1 & 0.541 & 0.02 \\
\hline B & -0.303 & 0.414 & 1 & 0.739 & 0.47 \\
\hline $\mathrm{C}$ & -0.388 & 0.336 & 1 & 0.678 & 0.25 \\
\hline D & 0.252 & 0.406 & 1 & 1.287 & 0.54 \\
\hline $\mathrm{E}$ & -0.338 & 0.306 & 1 & 0.713 & 0.27 \\
\hline $\mathrm{F}$ & -0.548 & 0.372 & 1 & 0.578 & 0.14 \\
\hline G & -0.027 & 0.348 & 1 & 0.973 & 0.94 \\
\hline $\mathrm{H}$ & 0.421 & 0.443 & 1 & 1.523 & 0.32 \\
\hline I & -0.369 & 0.283 & 1 & 0.691 & 0.20 \\
\hline
\end{tabular}

${ }^{1}$ Categorical variables assigned as baselines.

${ }^{2}$ Person performing $<30$ AI categorized to 1 group.

${ }^{3} \mathrm{~A}$ to $\mathrm{I}=$ letters identifying different persons performing $\geq 30 \mathrm{AI}$. 
Table 4. General estimating equation model for assessing the pregnancy incidence in Norwegian Red cows from the following predictors: days from calving to first AI (CFI), double AI (dAI), and season

\begin{tabular}{|c|c|c|c|c|c|}
\hline Item & $\beta$ & $\mathrm{SE}$ & $\mathrm{df}$ & Odds ratio & $P$-value \\
\hline Intercept & -0.185 & 0.274 & - & 0.83 & 0.50 \\
\hline CFI & 0.003 & 0.002 & 1 & 1.00 & 0.17 \\
\hline dAI, no ${ }^{1}$ & - & - & - & - & - \\
\hline dAI, yes & 0.537 & 0.317 & 1 & 1.71 & 0.09 \\
\hline Season, Jan-March ${ }^{1}$ & - & - & 一 & - & - \\
\hline Season, Oct-Dec & 0.383 & 0.240 & 1 & 1.47 & 0.11 \\
\hline Season, Apr-June & 0.320 & 0.270 & 1 & 1.38 & 0.23 \\
\hline Season, July-Sep & 0.534 & 0.241 & 1 & 1.71 & 0.03 \\
\hline
\end{tabular}

${ }^{1}$ Categorical variables assigned as baselines.

palpation did not deliver a calf after the current AI. Eleven were presented for a new AI, 12 animals were sold as milking cows, and 2 cows died. Culling reasons for the 12 animals were low fertility $(\mathrm{n}=3)$ and other reasons $(\mathrm{n}=9)$. Four animals aborted or calved 62 to $252 \mathrm{~d}$ of gestation, whereas 2 animals calved 296 and $297 \mathrm{~d}$ of gestation. Five animals were still alive $295 \mathrm{~d}$ after AI without a calving or a new recorded AI. No information was available regarding the last 3 animals.

\section{Low Fertility as a Culling Reason}

In the present study, 3.6\% (30/829) of the animals were culled because of low fertility $\leq 290 \mathrm{~d}$ after first AI. Nine animals were not presented for a new AI, and
3 were retrospectively diagnosed as pregnant. Twentyone animals were presented for a new AI.

\section{Pregnancy Diagnosis by PAG and Rectal Palpation}

Among 457 animals that calved after first AI and that had complete records regarding both PAG measurements and rectal pregnancy diagnosis, 444 had a PAG value $>2.5 \mathrm{ng} / \mathrm{mL}$ and were classified pregnant by veterinarians. Eight animals with PAG $\leq 2.5 \mathrm{ng} / \mathrm{mL}$ that were classified as pregnant by veterinarians calved between 270 and $287 \mathrm{~d}$ after first AI, whereas no animals that calved with PAG $\leq 2.5 \mathrm{ng} / \mathrm{mL}$ were classified as nonpregnant by veterinarians. Five animals classified

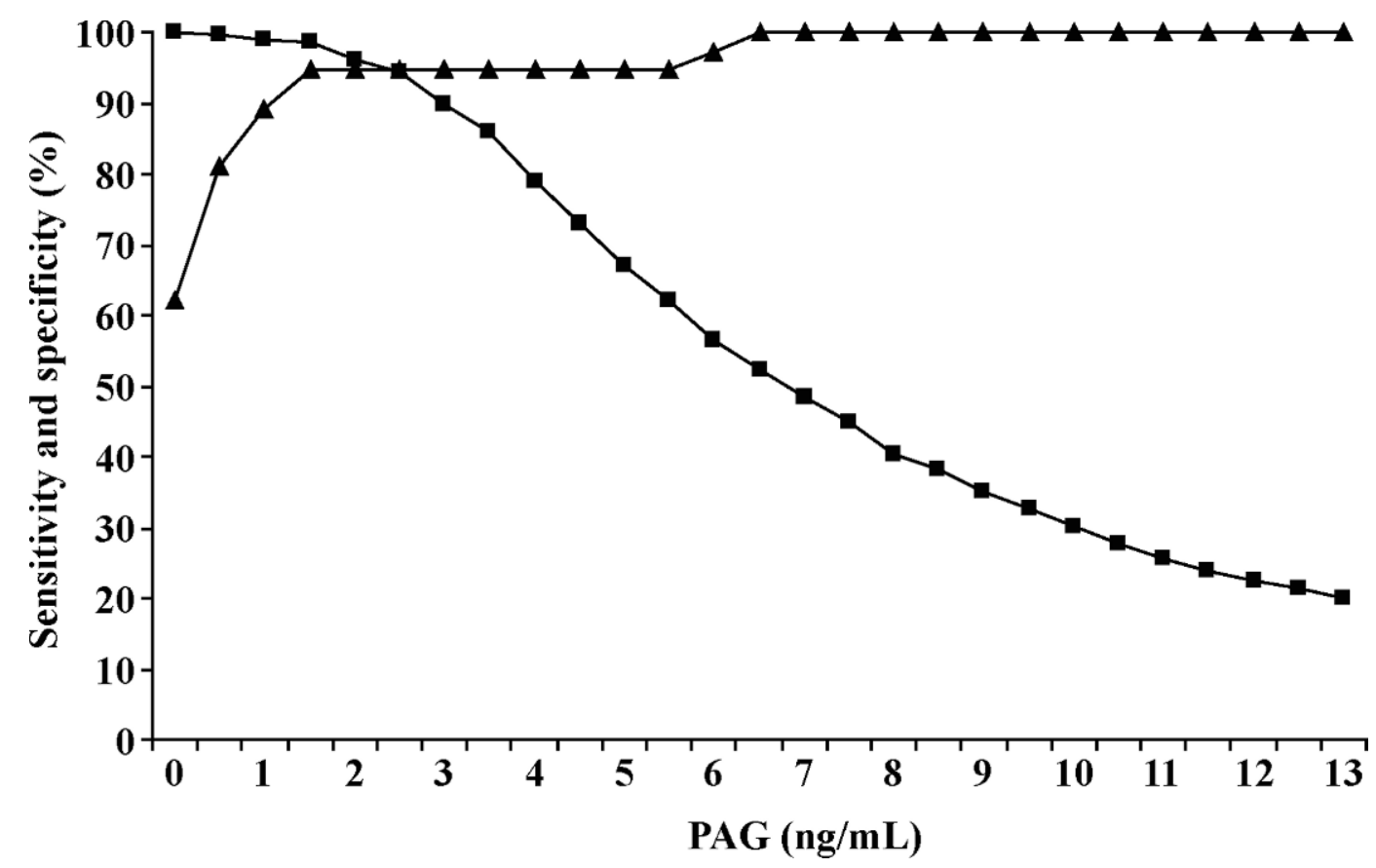

Figure 1. Sensitivity $(\mathrm{n}=473 ; \mathbf{\square})$ and specificity $(\mathrm{n}=37 ; \mathbf{\Delta})$ for the determination of pregnancy by measurement of pregnancy-associated glycoproteins (PAG) in Norwegian Red cows. 
as nonpregnant by veterinarians had a PAG value $>2.5$ $\mathrm{ng} / \mathrm{mL}$ and calved after first AI.

\section{DISCUSSION}

A nonreturn rate of $71.8 \%$ at $60 \mathrm{~d}$, a pregnancy incidence of $62.9 \%$ at $6 \mathrm{wk}$, and a calving rate of $56.3 \%$ after a single AI (Table 1) must be considered as indicators of high reproductive efficiency in Norwegian Red cows compared with previous and comparable studies in dairy cattle (Andersson et al., 2006; Cairoli et al., 2006), and superior compared with AI after induced estrus or timed AI (Lopez-Gatius et al., 2004; Howard et al., 2006). When cows subjected to double AI were excluded, the average NRR60d in Norwegian Red cows for 2005 was $72.7 \%$ (Refsdal, 2007), and the percentage of return rates within 0 to $3 \mathrm{~d}$ post-AI (double AI) was $12 \%$. These findings are well supported with those obtained in the present study.

Different threshold values for progesterone have been used both to indicate onset of estrus and to assess onset of luteal activity. Roelofs et al. (2006) reported milk progesterone concentrations $<2 \mathrm{ng} / \mathrm{mL}$ before ovulation. Milk progesterone concentrations $\geq 3 \mathrm{ng} / \mathrm{mL}$ were used as threshold value for luteal activity (Royal et al., 2000; Petersson et al., 2007). Accordingly, milk progesterone concentration $<3 \mathrm{ng} / \mathrm{mL}$ was used to determine that a cow was not in the luteal phase of the estrous cycle at $\mathrm{AI}$ in the present study. Thus, milk progesterone was only used to determine pregnancy in addition to pregnancy diagnosis by PAG or manual rectal palpation.

The observed increase in NRR60d from $68.1 \%$ in 1985 to $72.7 \%$ in 2005 for Norwegian Red cows (Refsdal, 2007) may be biased because of decreased ability of farmers to identify and rebreed nonpregnant animals, which corresponds well with an increase in herd size during the period (Østerås et al., 2007). It may be because of increased emphasis on fertility and health in the breeding strategy. Female fertility has been included in the total merit index since 1972 with relative weight on fertility between 8 and 15\% (Andersen-Ranberg et al., 2005). When the fertility index was calculated, the nonreturn rate at $56 \mathrm{~d}$ in heifers was weighted by $67 \%$, whereas first-lactation cows were weighted by $33 \%$ (Geno Breeding and AI Association, 2007). In other Nordic countries, nonreturn rate after $56 \mathrm{~d}$ in heifers and cows, CFI, days from first AI to last AI, and days open are commonly used for female fertility traits evaluation of bulls (Interbull, 2007).

Overall, NRR60d overestimated the pregnancy incidence by approximately 9\%. In heifers, the difference between NRR60d and pregnancy incidence was 6.9\%, whereas the same estimate for $>$ second-lactation cows was $11.3 \%$. This demonstrates that the nonreturn rate was subjected to more bias in older cows than among heifers. But culling of older cows before $60 \mathrm{~d}$ after AI was not an important reason for the lower pregnancy incidence; only 7 animals in the study group were culled before $60 \mathrm{~d}$ after first AI, and of these 7 animals, 4 were >second-lactation cows. The likely explanation of this bias is that the farmer presents an older cow for AI and when the cow returns to estrus the farmer decides to cull her at the end of lactation rather than performing a new AI. Consequently, NRR60d overestimates the pregnancy incidence.

The pregnancy incidence may vary with number of days from AI to pregnancy examination; this could be due both to the accuracy of pregnancy examination and to fetal mortality. In Norway, calculation of nonreturn rate after first AI includes all AI performed in heifers and cows. Reksen et al. (1999) reported that approximately $50 \%$ of Norwegian Red cows were pregnancy diagnosed, and that cows presented for pregnancy diagnosis were less likely pregnant than herd mates. Thus, if pregnancy diagnosis is used as a fertility measure in the calculation of the breeding index, care must be taken to avoid selection bias (Dohoo et al., 2003). In the future, pregnancy incidence in Norwegian Red cows may be approximated from the parity-specific differences between nonreturn rate and pregnancy incidence.

Lactation number was a significant predictor of the likelihood of pregnancy when all parity categories were included in the analyses, but when heifers were excluded from the analysis, lactation number did not affect the pregnancy incidence. It is known that reproductive performance in heifers is better than in cows, because of milk production and the risk of a prolonged period of negative energy balance leading to delayed ovarian activity (Butler and Smith, 1989).

The interval from calving to first AI, which was 84.4, 86.6 , and $84.9 \mathrm{~d}$ for first-lactation, second-lactation, and >second-lactation cows, respectively, was not associated with pregnancy incidence. The explanation for this could be a relatively long voluntary waiting period before first AI. The CFI interval in the present study was longer than that reported by Royal et al. (2000) in which the CFI interval increased from $74.0 \mathrm{~d}$ in the $1970 \mathrm{~s}$ to $77.6 \mathrm{~d}$ in the $1990 \mathrm{~s}$. The average CFI interval in Norwegian Red cows increased from 79 d in 1990 to 86 d in 2005 (Refsdal, 2007).

In addition to an increased weight on fertility in selection, the lack of association between milk yield and days from calving to $\mathrm{AI}$ on the likelihood of pregnancy could be because of the moderate milk yield in the Norwegian Red cows, which was 6,605 kg/cow-year in 2005 (Østerås et al., 2007). Yet the genetic potential for high milk yield in Norwegian Red is not fully exploited be- 
cause of the political framework present in Norway, which affects price mechanisms and feeding regimens such that milk yields remain moderate (Refsdal, 2007).

In the present study, $\mathrm{AI}$ in the luteal phase was performed in 4.9\% of the cows, which supports Andresen and Onstad (1979) and Grimard et al. (2006) who reported 4.4 and $5.0 \% \mathrm{AI}$ in the luteal phase, respectively. Cairoli et al. (2006) found that $10.2 \%$ of the cows showing spontaneous estrus were inseminated at high progesterone concentrations.

Sampling for PAG and rectal palpation for pregnancy was conducted at the same time, and both should express pregnancy or nonpregnancy independently of each other. Haugejorden et al. (2006) recommended that for cows inseminated $n$ days before $60 \mathrm{~d}$ postpartum, pregnancy diagnosis by PAG be carried out at 28 $+(n \times 0.5) \mathrm{d}$ of pregnancy. Using this formula, in the current study, PAG analysis was conducted in 6 animals before the recommended day of gestation. But in these animals, PAG values were $>7 \mathrm{ng} / \mathrm{mL}$, and additionally they were confirmed as pregnant by rectal palpation.

\section{CONCLUSIONS}

In conclusion, Norwegian Red cows have a relatively high reproductive performance, and the study population was probably representative of the population of Norwegian Red cows. Breeding for fertility traits over the last $35 \mathrm{yr}$ is likely an important factor contributing to such high fertility. For further estimation of the pregnancy incidence from nonreturn rate, it is important to be aware of differences in nonreturn rate and pregnancy incidence between younger and older cows. The study showed that the use of rectal palpation for pregnancy diagnosis is valuable, provided that veterinarians possess the necessary diagnostic skills.

\section{ACKNOWLEDGMENTS}

The authors would like to express their appreciation to the Norwegian Breeding and AI association, Geno, for their support. We would like to thank the veterinarians and AI technicians for their valuable field work, and the staff at the hormone laboratory for analyzing milk and blood samples. Support for the preparation of the anti-progesterone monoclonal antibody and the progesterone peroxidase conjugate was provided by the Estonian Science Foundation Grant 6065.

\section{REFERENCES}

Andersen-Ranberg, I. M., G. Klemetsdal, B. Heringstad, and T. Steine. 2005. Heritabilities, genetic correlations, and genetic change for female fertility and protein yield in Norwegian dairy cattle. J. Dairy Sci. 88:348-355.
Andersson, M., J. Taponen, M. Kommeri, and M. Dahlbom. 2006. Pregnancy rates in lactating Holstein-Friesian cows after artificial insemination with sexed sperm. Reprod. Domest. Anim. 41:95-97.

Andresen, Ø., and O. Onstad. 1979. Brunstkontroll og drektighetskontroll hos ku ved hjelp av progesteronbestemmelse i melk (Estrus detection and pregnancy testing in the cow using the milk progesterone test). Nord. Vet. Tidsskr. 91:411-421.

Butler, W. R., and R. D. Smith. 1989. Interrelationships between energy balance and postpartum reproductive function in dairy cattle. J. Dairy Sci. 72:767-783.

Cairoli, F., A. Mollo, M. C. Veronesi, B. Renaville, M. Faustini, and M. Battocchio. 2006. Comparison between cloprostenol-induced and spontaneous oestrus fertility in dairy cows. Reprod. Domest. Anim. 41:175-179.

Chagas, L. M., J. J. Bass, D. Blache, C. R. Burke, J. K. Kay, D. R. Lindsay, M. C. Lucy, G. B. Martin, S. Meier, F. M. Rhodes, J. R. Roche, W. W. Thatcher, and R. Webb. 2007. Invited Review: New perspectives on the roles of nutrition and metabolic priorities in the subfertility of high-producing dairy cows. J. Dairy Sci. 90:4022-4032.

Dohoo, I. R., W. Martin, and H. Stryhn. 2003. Veterinary epidemiologic research. Transcontinental, Charlottetown, Prince Edward Island, Canada.

Garbayo, J. M., B. Remy, J. L. Alabart, J. Folch, R. Wattiez, P. Falmagne, and J. F. Beckers. 1998. Isolation and partial characterization of a pregnancy-associated glycoprotein family from the goat placenta. Biol. Reprod. 58:109-115.

Geno Breeding and AI Association. 2007. Avkomsgransking, egenskaper, fruktbarhet (In Norwegian). http://www.geno.no/genonett/presentasjonsdel/GENO/avl/default.asp?menyvalg_id=311. Accessed April 16, 2008.

Grimard, B., S. Freret, A. Chevallier, A. Pinto, C. Ponsart, and P. Humblot. 2006. Genetic and environmental factors influencing first service conception rate and late embryonic/foetal mortality in low fertility dairy herds. Anim. Reprod. Sci. 91:31-44.

Haugan, T., O. Reksen, Y. T. Gröhn, E. Kommisrud, E. Ropstad, and E. Sehested. 2005. Seasonal effects of semen collection and artificial insemination on dairy cow conception. Anim. Reprod. Sci. 90:57-71.

Haugejorden, G., S. Waage, E. Dahl, K. Karlberg, J. F. Beckers, and E. Ropstad. 2006. Pregnancy associated glycoproteins (PAG) in postpartum cows, ewes, goats and their offspring. Theriogenology 66:1976-1984.

Howard, J. M., R. Manzo, J. C. Dalton, F. Frago, and A. Ahmadzadeh. 2006. Conception rates and serum progesterone concentration in dairy cattle administered gonadotropin releasing hormone 5 days after artificial insemination. Anim. Reprod. Sci. 95:224-233.

Interbull. 2007. Interbull routine genetic evaluation for female fertility traits.http://www-interbull.slu.se/Female_fert/ff-may07.html. Accessed April 16, 2008.

Lopez-Gatius, F., K. Murugavel, P. Santolaria, M. Lopez-Bejar, and J. L. Yaniz. 2004. Pregnancy rate after timed artificial insemination in early post-partum dairy cows after Ovsynch or specific synchronization protocols. J. Vet. Med. A Physiol. Pathol. Clin. Med. 51:33-38.

Lucy, M. C. 2001. Reproductive loss in high-producing dairy cattle: Where will it end? J. Dairy Sci. 84:1277-1293.

Østerås, O., H. Solbu, A. O. Refsdal, T. Roalkvam, O. Filseth, and A. Minsaas. 2007. Results and evaluation of thirty years of health recordings in the Norwegian dairy cattle population. J. Dairy Sci. 90:4483-4497.

Petersson, K. J., B. Berglund, E. Strandberg, H. Gustafsson, A. P. F. Flint, J. A. Woolliams, and M. D. Royal. 2007. Genetic analysis of postpartum measures of luteal activity in dairy cows. J. Dairy Sci. 90:427-434.

Philipsson, J., and B. Lindhé. 2003. Experiences of including reproduction and health traits in Scandinavian dairy cattle breeding programmes. Livest. Prod. Sci. 83:99-112.

Refsdal, A. O. 2007. Reproductive performance of Norwegian cattle from 1985 to 2005: Trends and seasonality. Acta Vet. Scand. 49:5. 
Reksen, O., A. Tverdal, J. R. Lang-Ree, E. Glattre, and E. Ropstad. 1999. Reproduction management of tethered cows on Norwegian dairy farms. Anim. Reprod. Sci. 57:141-151.

Roelofs, J. B., F. J. Van Eerdenburg, W. Hazeleger, N. M. Soede, and B. Kemp. 2006. Relationship between progesterone concentrations in milk and blood and time of ovulation in dairy cattle. Anim. Reprod. Sci. 91:337-343.

Royal, M. D., A. O. Darwash, A. P. F. Flint, R. Webb, J. A. Woolliams, and G. E. Lamming. 2000. Declining fertility in dairy cattle: Changes in traditional and endocrine parameters of fertility. Anim. Sci. 70:487-501.

SPSS Inc. 2004. SPSS Regression Models, 13.0. SPSS Inc., Chicago, IL.

Stokes, M. E., C. S. Davis, and G. G. Koch. 1995. Categorical data analysis using the SAS system. SAS Institute Inc., Cary, NC.
Thatcher, W. W., T. R. Bilby, J. A. Bartolome, F. Silvestre, C. R. Staples, and J. E. P. Santos. 2006. Strategies for improving fertility in the modern dairy cow. Theriogenology 65:30-44.

Waldmann, A. 1993. Enzyme immunoassay (EIA) for milk progesterone using a monoclonal antibody. Anim. Reprod. Sci. 34:19-30.

Waldmann, A. 1999. Monoclonal antibodies to progesterone: Characterization and selection for enzyme immunoassay in bovine milk. Hybridoma 18:289-296.

Xie, S., J. Green, J. B. Bixby, B. Szafranska, J. C. DeMartini, S. Hecht, and R. M. Roberts. 1997. The diversity and evolutionary relationships of the pregnancy-associated glycoproteins, an aspartic proteinase subfamily consisting of many trophoblastexpressed genes. Proc. Natl. Acad. Sci. USA 94:12809-12816.

Zoli, A. P., L. A. Guilbault, P. Delahaut, W. B. Ortiz, and J. F. Beckers 1992. Radioimmunoassay of a bovine pregnancy-associated glycoprotein in serum: Its application for pregnancy diagnosis. Biol. Reprod. 46:83-92. 